Images in...

\title{
Bilateral shoulder fracture, dislocation and replacement: a first presentation of epilepsy
}

\author{
Jonathan Richard White, Altaf Palejwala \\ Gastroenterology Department, Queens Hospital Burton, Burton-upon-Trent, UK
}

Correspondence to Dr Jonathan Richard White, whitj@doctors.org.uk

\section{DESCRIPTION}

A 60-year-old gentleman presented with posterior, fracture-dislocations to both of his shoulders, secondary to undiagnosed epilepsy. Simple posterior dislocations are more commonly associated with seizures and so this case demonstrates a highly unusual first presentation. Shoulder $\mathrm{x}$-rays on admission revealed bilateral comminuted fractures of the humeral head and neck. However, the complexity of this gentleman's orthopaedic injuries was not fully appreciated until days later when CT imaging of his shoulders showed bilateral posterior dislocations in addition (figure 1). This case demonstrates that bilateral posterior shoulder dislocations are implicated with unwitnessed seizures. Therefore, a high index of suspicion of a seizure disorder must exist to ensure that there is no delay in the diagnosis and treatment of the underlying condition. With regard to treatment of the shoulder injury, early diagnosis and prompt surgical intervention is needed to determine a good outcome. ${ }^{12}$ In conclusion, the patient underwent bilateral shoulder arthroplasty and was started on lamotrigine. Six months post discharge, he continued to be seizure free and he re-gained good long-term function of his shoulders.

Competing interests None

Patient consent Obtained.

\section{REFERENCES}

1. Tanner MW, Cofield RH. Prosthetic arthroplasty for fractures and fracturedislocations of the proximal humerus. Clin Orthop Relat Res 1983;179:2-308.

2. Robinson CM, Aderinto J. Posterior shoulder dislocations and fracturedislocations. J Bone Joint Surg Am 2005;87:639-50.
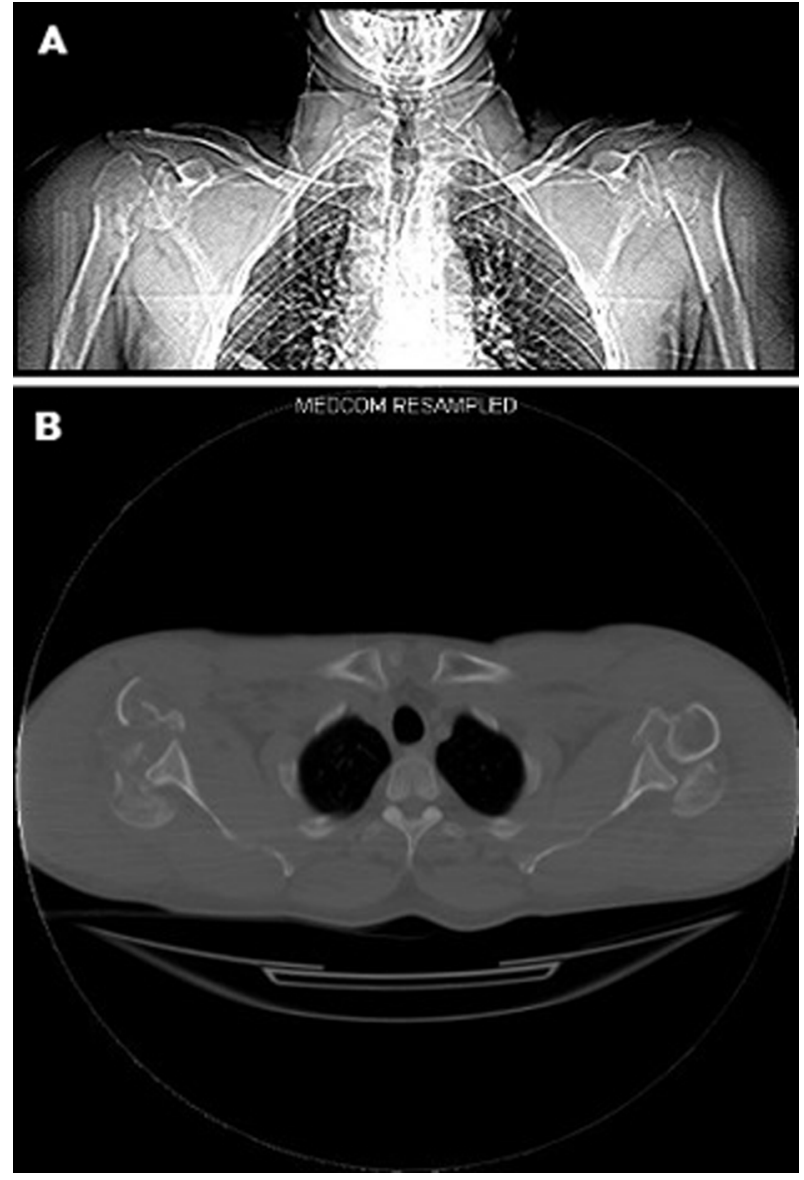

Figure 1 (A, B) CT scan of shoulders-Demonstrating bilateral comminuted fractures of the humeral head and neck with posterior dislocation. 


\section{BMJ Case Reports}

This pdf has been created automatically from the final edited text and images.

Copyright 2011 BMJ Publishing Group. All rights reserved. For permission to reuse any of this content visit http://group.bmj.com/group/rights-licensing/permissions.

BMJ Case Report Fellows may re-use this article for personal use and teaching without any further permission.

Please cite this article as follows (you will need to access the article online to obtain the date of publication).

White JR, Palejwala A. Bilateral shoulder fracture, dislocation and replacement: a first presentation of epilepsy . BMJ Case Reports 2011;

10.1136/bcr.09.2011.4830, date of publication

Become a Fellow of BMJ Case Reports today and you can:

- Submit as many cases as you like

- Enjoy fast sympathetic peer review and rapid publication of accepted articles

- Access all the published articles

- Re-use any of the published material for personal use and teaching without further permission

For information on Institutional Fellowships contact consortiasales@bmjgroup.com

Visit casereports.bmj.com for more articles like this and to become a Fellow 